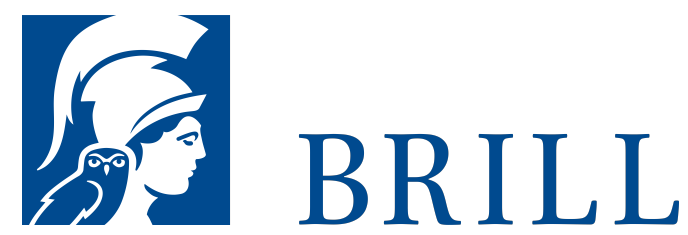

\title{
Machtphantasien in englischsprachigen Faust-Dichtungen: Funktionsgeschichtliche Studien
}

\section{Author: Paul Goetsch}

Als ein 'Schlüsselmythos der Neuzeit' (Watt) erfreut sich die Faust- Geschichte im englischen Sprachraum großer Beliebtheit. Neben dem Volksbuch und Marlowes Doctor Faustus haben verschiedene Prätexte die englische und amerikanische Entwicklung beeinflusst, vor allem Goethes Faust, Mary Shelleys Frankenstein, Spenglers Der Untergang des Abendlandes und Thomas Manns Doktor Faustus. Die vorliegende Untersuchung interessiert sich weniger für das einzelne Werk in seiner Abhängigkeit von Prätexten als für seine Stellung und seine historischen Funktionen in der Entwicklung der Faust-Mythe.

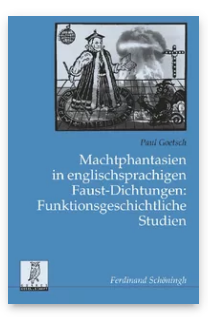

Pages: 303

Seiten

Language:

German

Subjects:

English \&

Anglophone, Literature and Cultural Studies Publisher: Brill | Schöningh

Series:

Beiträge zur englischen und amerikanischen Literatur, Volume: 26

E-Book (PDF) Released online: 3o Dec 2019 ISBN: 978-3657-76499-0 List price USD $\$ 63.00$

Paperback Publication date: 23 Apr 2008 ISBN: 978-3506-76499-7 List price USD $\$ 63.00$ 
For more information see brill.com

Order information: Order online at brill.com +44330 333 0049 | customerservices@brill.com Submission information: brill.com/authors

Titles published by Brill | Fink, Brill | mentis or Brill | Schöningh: +49(o)715413279216| brill@brocom.de 